\title{
PALEOBIOGEOGRAPHY OF DEVONIAN VERTEBRATES
} YOUNG, Gavin C., Onshore Sedimentary \& Petroleum Geology, Bureau of Mineral
Resources, PO Box 378, Canberra, ACT, 2601 AUSTRALIA

Five distinctive vertebrate faunas characterised by endemic taxa can be recognised for the Early Devonian (Euramerica, Siberia, Tuva, China, and East Gondwana). By Late Devonian time these faunal provinces are obscured by widespread taxa which also inhabited nonmarine aquatic environments, but indicate faunal communication between Gondwana, Euramerica and China. This marked change in pattern between the Early and Late Devonian may be attributed to intrinsic (evolutionary) or extrinsic causal factors. Dispersal capabilities of aquatic vertebrates may have increased during the initial gnathostome radiation of the Devonian, but a predominantly extrinsic cause (e.g. global change in geography or climate) is suggested by the similar pattern for marine invertebrate faunas of Early Devonian endemism and Late Devonian cosmopolitanism. Outstanding problems of Devonian vertebrate biogeography include faunal differentiation on the largest landmass of the time (Gondwana), and the nature of barriers and connections between East and West Gondwana, East Gondwana and South and North China, and West Gondwana and Euramerica. A vertebrate equivalent of the cool-water Malvinokaffric invertebrate faunal realm of the Siluro-Devonian is not clearly identified, but vertebrate data from southern Africa and south America are sparse.

Wide latitudinal distributions for some Late Devonian vertebrate taxa appear anomalous, and could indicate either reduced global climatic gradients, or erroneous paleogeographic base maps. There are difficulties in formulating a hypothesis of global warming and/or major paleogeographic change in a way which clearly distinguishes basic from interpreted data. Three major subdisciplines (paleomagnetism, paleoclimatology, paleobiogeography) contribute to Paleozoic paleogeographic reconstructions. Their data tend to be organised and represented in different ways, but each relies on the same principle of concordance with a general pattern (Young 1990). Degree of consilience of a hypothesis based on one data set (the extent to which it explains patterns within an unrelated set of data) is a primary criterion for accepting or rejecting the hypothesis. Apparent polar wander path representation facilitates testing of paleomagnetic data against those paleoclimatic or paleobiogeographic data which provide evidence of paleolatitude. However, as well as the simple indication of paleolatitude, biogeographic and some other qualitative data sets provide more complex evidence concerning connections or barriers between regions, for which APWP representation is not appropriate. Cladistic analysis of hierarchically organised data sets (Young, 1986, 1987) provides a means of integrating qualitative paleobiogeographic, paleoclimatic, and paleogeographic data such that inconsistencies in the evidence are emphasised, and the hypothesis is exposed to falsification. These ideas are illustrated using Devonian examples.

\section{REFERENCES}

YOUNG, G.C. 1986. Cladistic methods in Palcozoic continental reconstruction. Journal of Geology, 94:523-537.

YOUNG, G.C. 1987. Devonian palaeontological data and the Armorica problem. Palaeogeography, Palaeoclimatology, Palaeoecology, 60:283-304.

YOUNG, G.C. 1990. Devonian vertebrate distribution patterns, and cladistic analysis of palaeogeographic hypotheses, p.243-255. In W.S. McKerrow and C.R.Scotese (eds.), Palaeozoic Biogeography and Palaeogeography. Geological Society of London, Memoir 12. 